\title{
Men Alone, Men Entwined: Reconsidering Colonial Masculinity
}

\section{CHRIS BRICKELL}

\section{Introduction}

Two men pose together in an oval cut-out (Figure 1). The man on our right stands for the camera and lays his arm against the back of his seated companion. Both ignore the camera. They study a book instead, absorbed in the world portrayed in its pages. The pair shares a moment in time, a space, and also an intimate closeness; these are no men alone. What is their story, and what does it tell us about men's lives in late-nineteenth-century New Zealand?

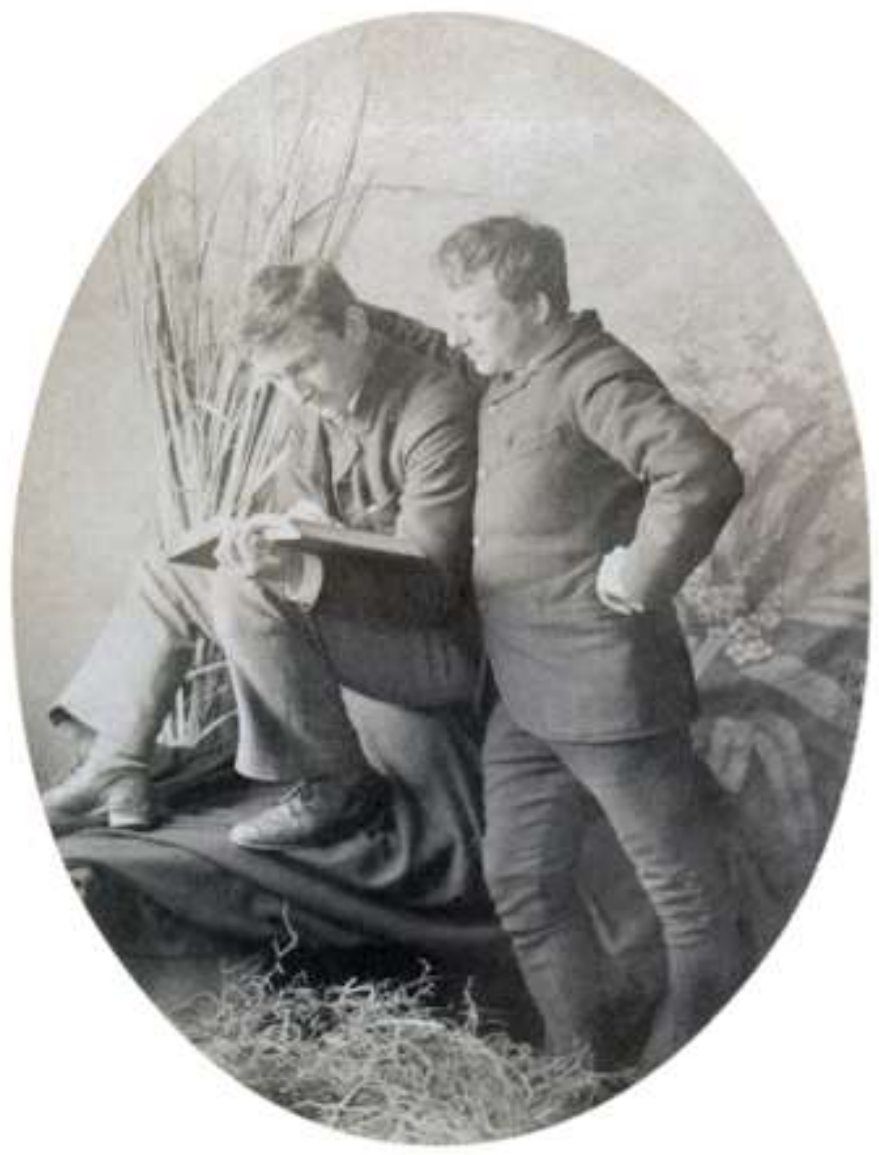

Figure 1: 'Charlie reading', 1889. PA1-q-962-43-2, Alexander Turnbull Library (ATL)

The man on our right is Robert Gant, an immigrant from England, a chemist and amateur photographer. When this photograph was taken, in 1889, Gant lived in Masterton and would have been 35. His friend is Charles Blackburn, 19, a clerk at the Masterton branch of the New Zealand Loan and Mercantile Agency. The setting appears curious at first glance, with its leaves, twigs and painted flowers, but there is an explanation. This is a stage set, installed in Masterton's Theatre Royal, where Gant, Blackburn and their many friends spent countless hours in rehearsals and performances. 
The image is one of 465 from two albums put together by Robert Gant in the early 1890s and now preserved in the Alexander Turnbull Library. Charles Blackburn's descendents owned the albums, and looked after them until 2007 when they shepherded the volumes into the Turnbull. This oval photograph, like many others in the albums, opens a world of colonial masculinity to us. Its intimate closeness makes us wonder how men interacted with one another back then, and to what extent male friendships involved touch, feeling and emotion. Gant's arm, draped warmly across Blackburn's back, raises questions about the borders between companionship and romance. The backdrop suggests a wider set of social connections: in the theatre, men played together and entertained their community.

This article uses some of Gant's photographs to explore these connections. It reconsiders what we 'know' about colonial Pakeha masculinities. We are all familiar with one particular portrait: the bush-feller or miner who worked hard and played hard, drank and fought, and kept his emotions in check when sober. Yet this view, depicted in countless popular and academic texts, does not square with this image of Robert Gant's. Indeed, it is at odds with most of his photographs. So what is going on?

I begin by examining the existing historiography on colonial men's lives. Much of this historiography offers a very partial account of nineteenth-century New Zealand masculinity. A number of concerns stand out. First, male friendship - mateship, in the antipodean context - has often been viewed as weak and incidental, or fleeting and unemotional. Was this necessarily the case? Second, the full spectrum of socio-economic experiences is often collapsed in favour of a focus on working-class masculinities. Middle-class lives - like those of Robert Gant and his friends - remain oddly underexplored for this period. Third, a presumption of 'atomism', to borrow Fairburn's term, has proved hard to shake. 'The concept of 'social capital' offers one way to closely examine questions of aloneness and togetherness. Fourth, 'affect' - that realm of emotion, touch and feeling - is usually ignored or underplayed in the history of New Zealand masculinity, but it too is worth another look. And last, but not least, homoerotic possibilities have frequently been left out or discounted, and this elision reflects latetwentieth-century assumptions rather than nineteenth-century ones. As scholars work through these concerns, we might reconsider the relationships between men and explore the intersections between different types of colonial masculinity.

Robert Gant's photographs constitute a particular kind of resource for historical research. In general terms, the history of photographs is a history of individuals, families, places and activities, as well as ideas, gender and class relations. As Dalley writes, pictures are useful sources in 'the histories of less tangible things, such as emotions, sensibilities, mentalités, and beliefs'. 2 Sometimes they give up the 'involuntary confessions of history, the things tucked away in the corner of images'. ${ }^{3}$ There appear to be few, if any, primary texts that explain the links between male friendship, affect and eros in nineteenth-century Masterton, and photographs are all the evidence we have. Fortunately, many of Gant's pictures are captioned. Researchers can take this information and trace names through other sources: newspapers, local histories, family reminiscences. From there, we can map networks, connections and community activities. These images open the door to a wider investigation, and they gesture towards a fluid, complex and multidimensional account of settler masculinity.

Journal of New Zealand Studies NS13 (2012), 11-33. 


\section{Assuming aloneness}

Without a doubt, men forged intimate connections with one another in nineteenth-century New Zealand. I have explored these in some depth in my own earlier writing, evoking the lives of 'mates and lovers' from colonial to contemporary times. My book-length investigation was partly a response to the scholarship of the last thirty years, much of which overlooked the emotional and erotic possibilities of New Zealand's male history. ${ }^{4}$ It is worth revisiting some of this scholarship in a little more detail.

During the late 1980s and the 1990s, in New Zealand and elsewhere, scholars began to study men's lives in earnest. Most agreed that masculinity is an historical creation, not a biological or social given, and that forms of masculinity change 'in relation to historical events and changing economic and social relations'. In this view, individual lives are informed by wider social contexts and processes. As the 1990s wore on, the 'cultural turn' shifted the focus from material circumstances to discursive and symbolic constructions, but most theorists held fast to the presumption of contingency and change. ${ }^{6}$

In New Zealand, the emerging historical picture was a rather Barry Crumpish one. Readers learned about the bush, the goldfields and the railways, where all-male 'crews' lived 'a rough and tough lifestyle, involving fifteen pounds of meat a week and no bed sheets', and expressed themselves primarily in bingeing, brawling and occasional whoring. ${ }^{7}$ These men were inclined to stoicism and determined to master their emotions: 'In a world of aching muscles and broken limbs, of sodden huts and monotonous food, it simply did not pay to have too sophisticated a sensitivity'. ${ }^{8}$ Such dynamics were profoundly gendered. The 'association of women with the sphere of emotions and tastes undoubtedly served to confirm this emotional insensitivity', Phillips writes. 'Men thought of their emotions as a weakness, and they were not going to display emotions before their peers'. ${ }^{9}$

This frontier masculinity - pugilistic and emotionally reticent - was also associated with 'atomism', a tendency to individualism and weakly bonded communities. Atomism, Fairburn writes, dominated the period before 1880 in particular. ${ }^{10}$ Fairburn's atomisation thesis is well-known; in a scattered population with few kinship ties, social isolation was 'the prevailing tendency', and "each individual was a "man alone" in the sense that his associations tended to be few and fleeting'. ${ }^{11}$ The loneliest men of all lived in small settlements and the back country, where drunkenness and interpersonal violence were common among the gum diggers, waggoners, gold miners and shepherds. ${ }^{12}$ In a world characterized by an 'extreme individualism of the single male', enduring mateship was rare. ${ }^{13}$ Fairburn's periodization is a little unclear. He suggests atomism was in decline by 1880 , but he uses examples from the 1880s and 1890s - the period in which Robert Gant's albums were produced - to support his thesis.

Many men did indeed fit this image of the 'man alone'. Some spent years on the road, mostly in their own company, moving from job to job. State hangman Tom Long, for instance, humped his swag through the Wairarapa district between assignments. ${ }^{14}$ Labourer James Cox drifted his way across the same landscape, with its 'clumps of native forest trees in the foreground and the rugged, snow-capped ranges in the distance'. ${ }^{15}$ Men did not all live the same kinds of lives, though, and we cannot apply this image of masculinity to an entire society. Daley takes Fairburn to task for his broad-brush, statistically-based approach that tended to gloss over the social life of any given community or district. Drawing on her in-depth study of Taradale, Daley shows that

Journal of New Zealand Studies NS13 (2012), 11-33. 
detailed community studies reveal much about the intricacies and nuances of colonial sociability. While some male colonials were probably atomised, she concludes, others were well-embedded in community networks. ${ }^{16}$ Wright, too, writes that nineteenthcentury New Zealand society was built around a broad range of social connections, including family and marriage ties, friendships, clubs and sporting organizations. ${ }^{17}$

Likewise, we cannot assume emotional reticence too readily. Phillips' chapter on 'the pioneer man', for instance, with its rough-and-ready characters, draws mostly from a very particular set of qualitative sources: published tales of settler life. Yarn-spinners replicate popular ideals of masculine robustness, embellish their own manly deeds in the process, and are unlikely to describe their emotional lives for their readers. Phillips' overall depiction is gritty and robust, but occasionally he does soften his portrayal of men's emotional reticence. Many itinerants had 'cobbers' to keep them company for varying periods of time, he explains. Men combined accommodation and domestic duties on the goldfields and in the bush, and they offered one another 'solace, encouragement and mutual aid' in times of difficulty. ${ }^{18}$ While 'mateship was often a relationship of circumstance', Phillips writes, sometimes men's relationships inspired 'ties of manly sympathy'. ${ }^{19}$

Aspects of class are also underplayed. Those more susceptible to atomism - the itinerant bush-fellers, labourers and gold miners - fill the pages of our history books, but middle-class men are mostly ignored. On the goldfields, 'it was workmen who crowded the diggings most eagerly', Eldred-Grigg writes, and 'laughed at the makeshifts of toffs who came bumbling after gold'. ${ }^{20}$ In his Penguin History of New Zealand, King mentions the 'rich male culture' of bushmen, but other men's cultures are absent from his account. ${ }^{21}$ Among the pages of Fairburn's The Ideal Society and its Enemies, the middleclass man appears as a shadowy 'other', a foil to the working-class masculinity that forms the basis of the narrative. ${ }^{22}$ Urban studies follow much the same pattern. Olssen's work on Dunedin's southern suburbs provides a detailed account in some ways, but this was a workers' community where 'all but a handful of professionals worked with their hands'. ${ }^{23}$ Olssen evokes more 'well-to-do' men only in passing, and their spectral presence serves primarily to underline working-class solidarity. ${ }^{24}$

So who were these middle-class New Zealanders? In her discussion of nineteenthcentury economic life, Toynbee defines the middle-class 'in terms of education or ownership of the means of production where this is confined to family businesses in general'. ${ }^{25}$ Small shopkeepers, managers, officials and clerks make up this group. Wright later adopted Toynbee's definition, and added doctors, lawyers, store-owners and artisans to the list. ${ }^{26} \mathrm{He}$ notes that, in general terms, the middle-classes aspired to gentility while also exalting a hard day's work. ${ }^{27}$

Masterton's middle-class expanded during the 1880s. By 1889, the town was home to a magistrate and three doctors, five solicitors, six journalists, three bank managers, seven engineers, a postmaster and stationmaster, and numerous local body clerks, bank employees, and office staff at New Zealand Loan and Mercantile Agency, the stock and station agents. ${ }^{28}$ Many of Robert Gant's friends were aged in their twenties at the end of the 1880s, and most worked as clerks. Charles Blackburn and Harry Mowat had office jobs at the 'Loan and Merc', Edmund Porritt at the Masterton Magistrate's Court, Harry Perry at the North Wairarapa County Council, H.B. Dyer at the Bank of Australasia, Robert Coleman at the Bank of New Zealand, Harry Rowe at the Bank of New South 
Wales, and James Kibblewhite and Herbert Rockel at the Masterton Post Office. Bert Erskine was a teacher, H.A. Gaskill a draper's assistant. In the decades that followed, Mowat went on to become a real estate agent, Porritt a solicitor and Stipendiary Magistrate, Erskine the president of the New Zealand Educational Institute, and Perry began his own successful stock and station agency. ${ }^{29}$

Robert Gant spent his last 25 years with a male lover, the draper Charlie Haigh. ${ }^{30}$ Gentility may have been a characteristic of the New Zealand middle-class, but we cannot be too quick to assume its meaning or significance in terms of sexuality. King suggests that those involved in 'homosexual behaviour' had very little space in which to manoeuvre in colonial New Zealand. They could marry women, remain celibate, lead an illicit life, or flee the country. ${ }^{31}$ 'Taking its lead from the missionaries', Belich writes, 'Pakeha society built up a substantial homophobia'. ${ }^{32}$ These accounts assume that harsh penalties for some acts - a conviction for sodomy earned a minimum of ten years' imprisonment, although other forms of male-male connection remained legal until 1893 reflected a uniformly condemnatory social climate. Although the legal wording railed against 'felony' and 'abomination', many colonial antipodeans remained unmoved by consenting sex between men, and few had much to say about it publicly. ${ }^{33}$

There is another problem: assumptions about 'homophobia' do not sit well with nineteenth-century society. In our own time, as Sedgwick points out, male bonding is typically 'characterized by intense homophobia, fear and hatred of homosexuality'. ${ }^{34}$ But the dynamic of homophobia rests upon the 'heterosexual/homosexual' binary, a more recent development. This binary encodes peculiarly modern ideas about sex, love, intimacy and the gendered connections between them. ${ }^{35}$ Not until the mid-twentieth century would this binary begin to take hold in New Zealanders' thinking. As we will see, older types of male relationship sometimes brought homosociality and homoeroticism together rather than forcing them apart.

The photographs of Robert Gant and his friends invite us to revisit these interlocking themes. Sexual connection, friendship and emotionality all spring from particular dispositions of aloneness and togetherness, and I turn to this last theme first.

\section{Rethinking aloneness/togetherness: social capital}

Questions of social connectedness have exercised the minds of scholars in recent years. Putnam's Bowling Alone examined trust and cohesiveness in modern American society, and popularized the concept of 'social capital'. ${ }^{36}$ However, the term itself has a much longer history. In 1916, educational sociologist L.J. Hanifan used 'social capital' to describe a coalescence of goodwill, fellowship, trust and mutual sympathy. These virtues, Hanifan suggested, underpinned social cohesion in rural American communities. ${ }^{37}$

French theorist Pierre Bourdieu further developed the concept. 'Social capital', he suggested in 1983, 'is the aggregate of the actual or potential resources which are linked to possession of a durable network of more or less institutionalized relationships of mutual acquaintance and recognition - or, in other words, to membership in a group'. ${ }^{38}$ This groupness, he continued, required common reference points, strategies for 'reproducing social relationships that are directly usable in the short or long term', and obligations 'subjectively felt', including 'feelings of gratitude, respect, friendship'. Bourdieu proposed that community activities and public events encouraged 'a continuous series of exchanges' and further reinforced groups and networks. ${ }^{39}$

Journal of New Zealand Studies NS13 (2012), 11-33. 
Social capital is the antithesis of Fairburn's atomism, and it makes an appearance in late-nineteenth-century Masterton. When we lift the names from the captions of Gant's photographs and sit down with local history books and microfilmed copies of the Wairarapa Daily, a rich community life comes into focus. Local events included concerts, plays, picnics, sports, roller skating, public lectures and church socials, some of which attracted many participants. In January 1887, one 'vocal and instrumental concert' at the local drill hall attracted an audience of three hundred - some 13\% of Masterton's 2,200-strong population. ${ }^{40}$ Rugby and cricket clubs, lodges, the rifle volunteers (a precursor to the modern Territorial Forces), theatre groups, schools and churches all fostered social connections, and sometimes whole organizations came together. In May 1888, when the Masterton Football Club held its Queen's Birthday entertainment, members of the Masterton Amateur Dramatic Club provided its centrepiece: a 'highly amusing farce'. ${ }^{41}$ A year later, at the same event, the members of the Masterton Philharmonic Society came out in force - in fancy dress, no less. ${ }^{42}$

We can see these kinds of overlaps in Robert Gant's friends' lives. Some activities were pursued in mixed-gender groups; others were crucibles of male culture. ${ }^{43} \mathrm{~A}$ member of the United Ancient Order of Druids, postal clerk James Kibblewhite also belonged to Masterton's football and cricket clubs, whose soirées he helped to organize, and to the local rifle volunteers. Kibblewhite took to the stage too. He performed in the occasional farce, and appeared as a jury member in a Masterton production of Gilbert and Sullivan's Trial by Jury. The leisure life of local authority clerk Harry Perry followed much the same trajectory: he played rugby and cricket, and was a regular on stage. Loan and Mercantile clerk Charles Blackburn enjoyed winter and summer sports. He was a fine pianist and occasional actor: in one play - French Before Breakfast - he appeared in drag, as a Mrs Spriggins. William Iggulden was a chorister at St Matthew's, the 'possessor of an excellent voice', a boxer of some repute, and a real talent in the Red Star Football Club. ${ }^{44}$ Although Fairburn is pessimistic about the influence of such voluntary organizations, suggesting 'they were too weak to exert much influence on their adherents', he rightly points out that many settlers involved themselves in more than one group. ${ }^{45}$

Figure 2 charts some of the links. Each line represents a connection between a pair of men in a community organization, each of whom features in Gant's photograph albums. The men's community involvement is deduced from newspaper reports from 1888 and 1889. ${ }^{46}$ By virtue of his shared involvement with the Masterton Philharmonic Society, for example, Gant knew Kibblewhite, Kibblewhite knew Perry, Perry knew Gant, and so on. This diagram shows the links for six organizations: the Masterton Philharmonic Society, the Red Star Football Club, the Masterton Football Club, the Masterton Volunteers, the Masterton Cricket Club, and St Matthew's Church. While we would expect these men to have organizations in common, given their appearance together in the albums, it is notable that all of the men belonged to several organizations, and to several types of organizations (theatrical, religious and sporting).

Journal of New Zealand Studies NS13 (2012), 11-33. 

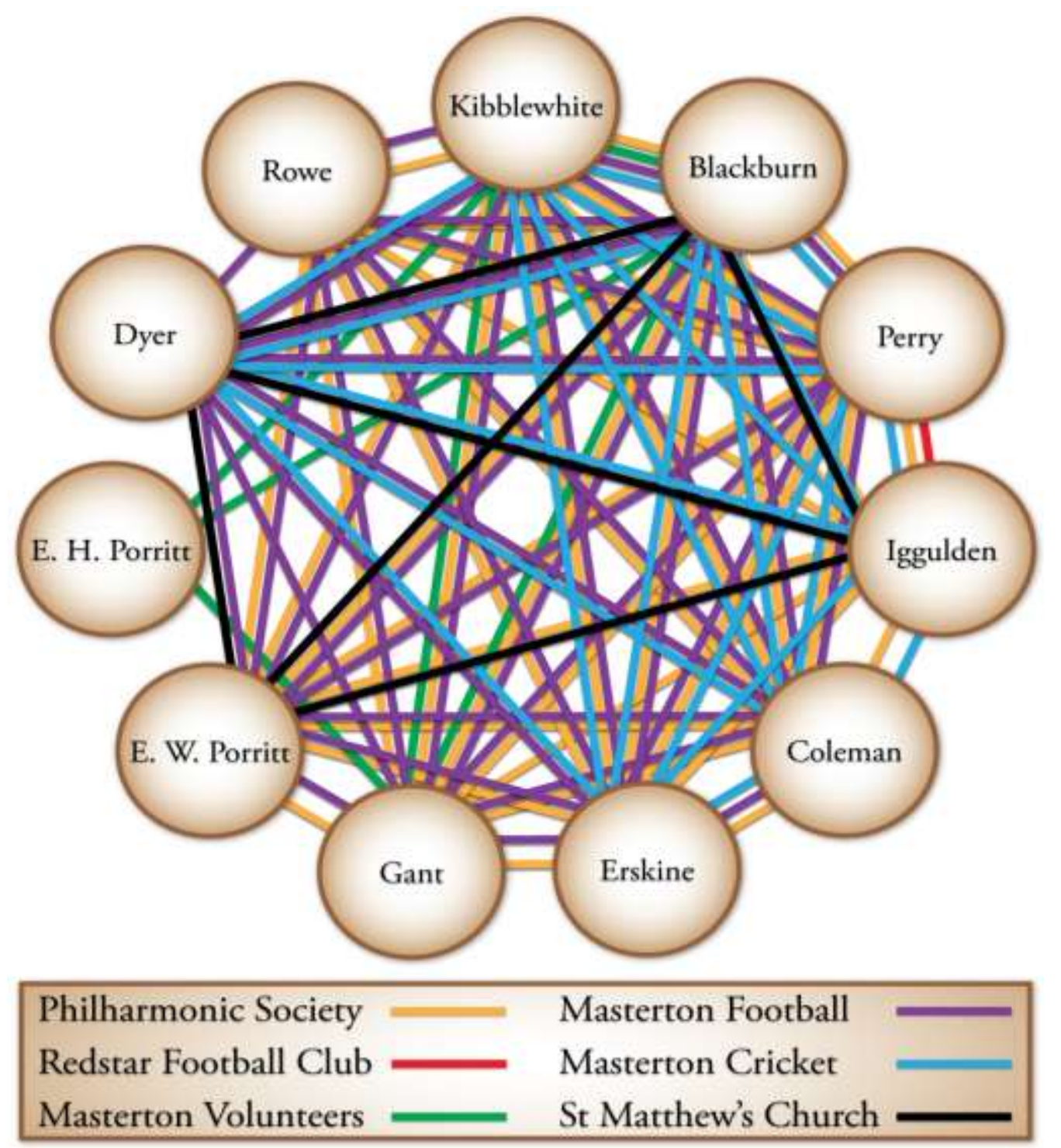

Figure 2: Community connections: a network diagram.

This network is dense, and the degree of overlap is conducive to the formation of strong social capital. It neatly illustrates one of Bourdieu's key criteria: 'a durable network of more or less institutionalized relationships of mutual acquaintance and recognition'. ${ }^{47}$

Robert Gant played a central role in these relations of social capital, qualitatively as well as quantitatively. In his day job as a chemist in T.G. Mason's shop, he engendered trust among his customers. When locals visited the shop for assistance, Gant dispensed the relevant potions - lime juice, castor oil and glycerine cucumber jelly, and all the rest - and no doubt he gave out the odd bit of advice. ${ }^{48}$ In the evenings and weekends, he stage-managed productions for the Masterton Philharmonic Society and sang in fundraising concerts in churches and lodges. Although Gant does not appear to have been sporty, the Masterton Football Club called him onto their social subcommittee. In that capacity, he helped to organize the club's weekly dances and the occasional ball. ${ }^{49}$ After one AGM, the Wairarapa Weekly newspaper recorded a vote of thanks 'to the ladies and 
gentlemen who by their kind assistance contributed in no small measure to our success last season at the dances and at the entertainment, more especially to Messrs Keisenberg and Gant, who were ever ready to render us all the assistance in their power' ${ }^{50}$

These community contributions came to define Robert Gant in the public mind. When he left Masterton in 1891 to return to England for a holiday, the town's residents held a concert in his honour. 'It should hardly require a special notice to remind the public of the complimentary concert to be tendered to-night to Mr R. Gant', wrote the reporter at the Wairarapa Daily, before continuing eulogistically:

During eight years' residence Mr Gant has never been known to refuse his services at the call of charity. Every denomination, every society, public institution, Fire Brigade, Volunteer corps, Football and Cricket Club has at different times made use of his talent. Even Carterton and Greytown have availed themselves of his ready kindness. Of the Dramatic and Philharmonic society he was the leading spirit, and many times he has delighted large audiences by his music and histrionic gifts. In his capacity as a private citizen he has enjoyed the esteem of all who have come into contact with him. ${ }^{51}$

In this corner of the world, in this middle-class group, men were hardly ever alone. They fostered strong social bonds, sometimes in mixed-gender company and sometimes in single-gender settings. A range of organizations bound men together and some, including the photographer who would capture and then commemorate proceedings, took an especially central role.

What happened, though, when people moved about? Geographical mobility was a significant factor in colonial men's lives. Many New Zealanders, including Gant and some of his friends, upped sticks and relocated to other parts of the colony. While Fairburn suggests that high levels of mobility led to weak social bonds, high levels of alienation and violence, Ballantyne has more recently proposed that 'the circulation of people, money, goods and services was the lifeblood of colonial life'. ${ }^{52}$ Travels and relocations pulled some relationships apart, but they also allowed people to expand their networks over a wider terrain.

Masterton was not as isolated as we might think, and its citizens' ideas about social life and identities developed as they moved from one location to the next. The rail timetable allowed Wairarapa residents an afternoon in Wellington before their return over the Rimutakas. ${ }^{53}$ Although the trip took five hours each way, Mastertonians made the most of it. On a hot summer's day in 1887, for instance, a crowd piled into a train and headed over the mountain range; a tram and horse bus-ride later, the punters arrived at the regatta and races at Island Bay. ${ }^{54}$ Rugby teams regularly left the district on tour and headed as far away as Dunedin. Conversely, a touring English team arrived in Masterton in September 1888. Some of those who moved out of the district came back to visit. James Kibblewhite left for a job in Wellington early in 1889, but returned soon afterwards to face his old team-mates across the rugby field. ${ }^{55}$ A photograph of Kibblewhite, Gant and Bert Erskine is captioned 'A frequent visitor in the later years' (Figure 3). In such moments, as Ballantyne writes, people took their place in 'dense and fluid webs of social relations'. 56 


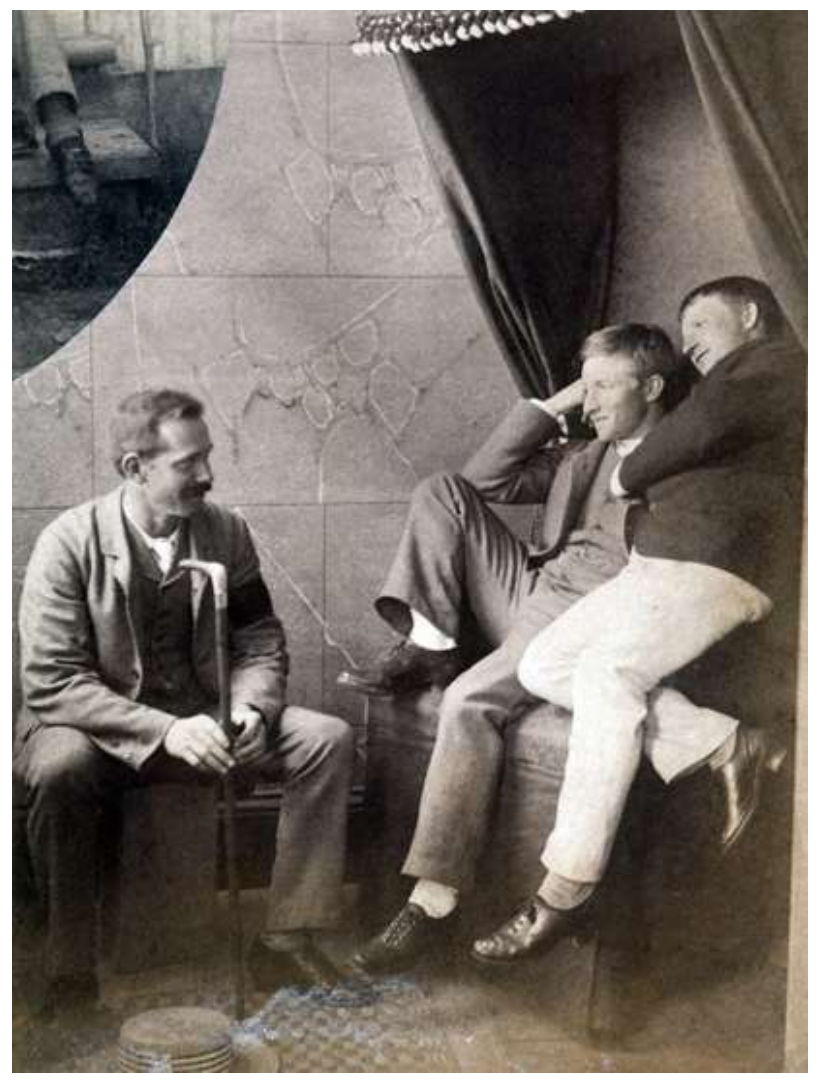

Figure 3: 'A frequent visitor in the later years': Kibblewhite, Gant and Erskine, 1888. PA1-q-962-2-5, ATL.

The railway was an important vector of circulation, and a valuable link in the chain of social capital. Snaking north from Wellington, the line opened as far as Featherston in 1878, and trains steamed across the plains to Masterton from 1880. As Ryan points out, rugby was strongest in those areas linked together by rail, but rugby and the races were not the iron horse's only beneficiaries. ${ }^{57}$ Strong transport links proved indispensable for touring entertainers. In January 1888, Masterton residents hosted the accomplished 'Miss Lilly Davies, the London prima donna, and Mr Wynn McLean, the celebrated violin soloist from the Paris Conservatoire', supported by 'some good Wellington amateurs'. 58 Conversely, Gant travelled by rail to Wellington and steamer to Nelson and performed there. Travel was easier than it had been in the late 1870s, when Gant and other troupe members tripped around the lower North Island and upper South. Then they had to stop on occasion to push their stagecoach, laden with props and costumes, through mud and slush. $^{59}$

Among all the comings and goings, Masterton residents held their own entertainments. There was a packed programme of concerts, plays and operas, many of which drew upon the talents of the men who appear in Robert Gant's albums. Indeed, the Wairarapa Daily described Masterton as 'a town boasting of so much amateur musical talent' ${ }^{60}$ Gilbert and Sullivan's operas were popular, especially H.M.S. Pinafore and Pirates of Penzance. These led to a proliferation of pirates and sailors; there was many an opportunity to don costumes, act out new scenarios and evoke other worlds (Figure 4). 


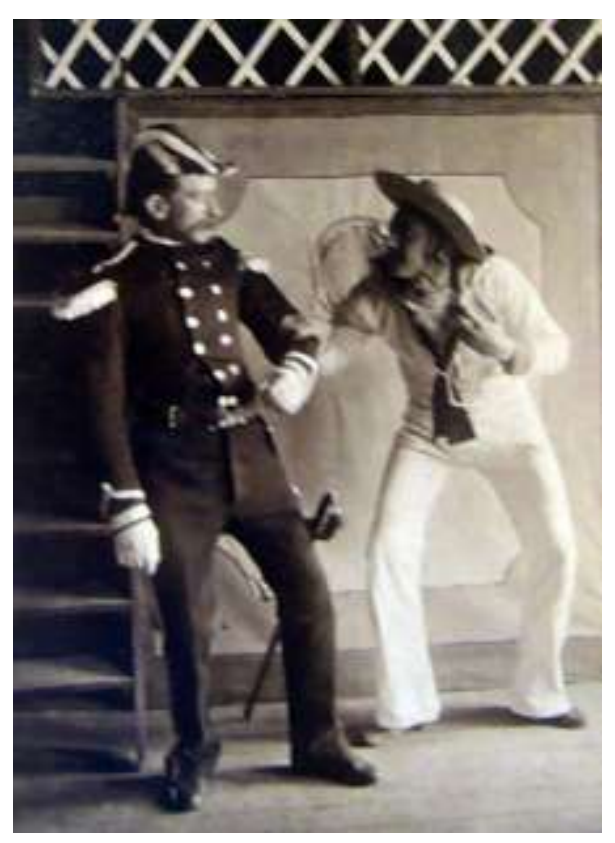

Figure 4: In an 1888 performance of H.M.S. Pinafore, Dick Deadeye (H.A. Gaskill) quarrels with Captain Corcoran (S.H. Wickerson). 1888. PA1-q-963-16-5, ATL.

These kind of social capital-forming activities were not unique to the Wairarapa. Other towns offered similar opportunities. Hawera's 3,000 inhabitants formed an Orchestral Society and an Operatic Society, and Gore locals enjoyed Gilbert and Sullivan's H.M.S. Pinafore. ${ }^{61}$ As Ballantyne demonstrates, the Southland town boasted a 'rich local social life, full of picnics, balls, dances, lectures, dramatic productions, "entertainments", society meetings, public debates, public shows and exhibitions, and sporting matches', all of which brought settlers together. ${ }^{62}$ In the smaller settlement of Hampden, northern Otago, one settler remembers the travelling troupes and frequent public lectures - 'none missed Hampden' - as well as the church concerts and picnics. ${ }^{63}$

Back in Masterton, some of the most mobile men were highly active in the town's social life. Their networks may not have been especially durable, but their 'relationships of mutual acquaintance and recognition', to borrow Bourdieu's wording, were institutionalized to some degree. As Daley observes of Taradale, 'relationships between men may have been short-term but that does not mean they were not intense'. ${ }^{64}$ Draper's assistant H.A. Gaskill arrived in the Wairarapa late in 1886 and was gone two years later. In the meantime, he sang in numerous football club concerts, played 'Dick Deadeye' in H.M.S. Pinafore, and helped to establish an amateur group of Christy minstrels. ${ }^{65}$ Harry Rowe was another example, a bank clerk who lived in the district for two years and participated in several stage productions. Among other appearances, he was a most military-looking Sir Joseph Porter in Pinafore. Porter's and Deadeye's costumes soon returned to their hangers, Rowe and Gaskill moved on, but others no doubt took their place. 


\section{Intimate masculinities}

Robert Gant's photographs - and reports in the local newspaper - suggest that community closeness sometimes segued into physical intimacy. In a post-Pinafore dance, Rowe, as Porter, waltzed arm-in-arm with Gant, who had established himself as a lively and convincing Buttercup ${ }^{66}$ Unfortunately no photograph of that event survives, but elsewhere men stood or sat together and looked at one another fondly. Figure 5 is but one example. Titled 'Indoor walk', it shows Gant and Kibblewhite attached at the shoulder and the knee; each man looks warmly at his companion.

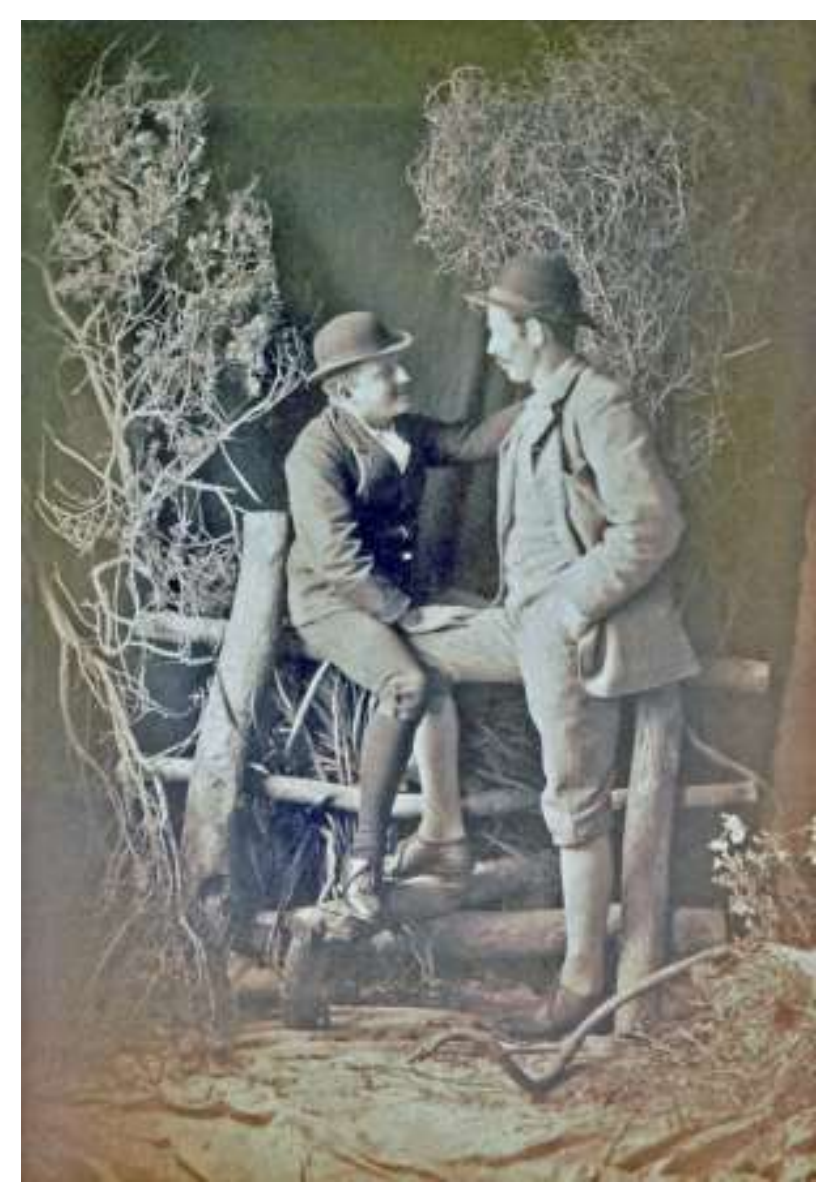

Figure 5: 'The indoor walk', c.1889, Gant (left) and Kibblewhite among a foresty backdrop on stage. PA1-q-962-53-5, ATL.

As Sedgwick explains, 'the structure of men's relations with other men' changes across time and place, and associations take different forms. ${ }^{67}$ Many northern hemisphere historians have documented the specificities of nineteenth-century male friendship. Men married in their mid-to-late twenties, they point out, and distinct 'bachelor cultures' developed among unmarried men. ${ }^{68}$ Among the Mastertonians, Charles Blackburn and William Iggulden married at 24, H.B. Dyer and Harry Perry at 26, James Kibblewhite at 27 and Edmund Porritt at 28. 
In this context, Gay writes of 'the cult of friendship' that 'permitted men to declare their love for other men - or women for other women'. 69 'Romantic friends' often announced their devotion to one another, promised emotional support, and shared physical intimacies. ${ }^{70}$ Gillis maps out a pattern reasonably common among middle-class European men until the mid-nineteenth-century. 'Theirs was a generation that could still weep openly without fear of being called effeminate', he writes; '[ $t]$ hey enjoyed a cult of warm, open male friendship'. ${ }^{71}$ These men's social world consisted of 'small, intimate circles of friends'. ${ }^{72}$ Our Masterton men may not have wept openly, not that we can see, at least, but their intimate relationships are palpable. They hug, touch, and drape their arms around one another's shoulders.

The romantic friendship model was based on an important ideological distinction. Historians suggest that nineteenth-century men drew a line between 'pure' (or 'spiritual') love (agape) on the one hand, and carnal desire (eros) on the other. ${ }^{73}$ To show love or adoration was not in itself an expression of sexual feeling. The love of comrades could be, and often was, strictly platonic. It could also involve more than one man at once, as it did in Figure 6, where three men - from left to right, Bert Erskine, Gant and Charles Blackburn - sit on a park bench and link arms. James Kibblewhite, meanwhile, focuses his tactile attention on his dog.

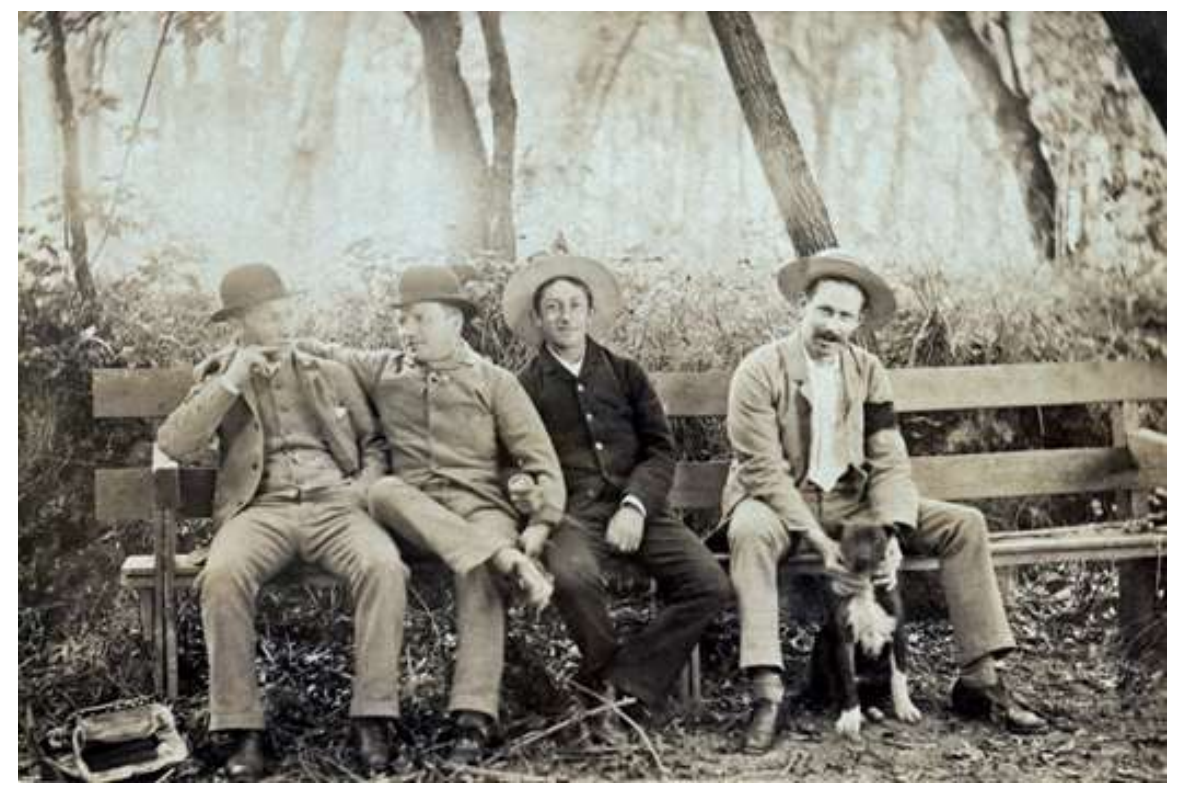

Figure 6: 'Makora, last Sunday in 1888' with, from left to right: Erskine, Gant, Blackburn and Kibblewhite. PA1-q-962-29, ATL.

These are moments of heightened 'affect', to use a term popular among psychologists and cultural theorists. ${ }^{74}$ 'Affect denotes the attempt to articulate the intensities that are sensed and perceived by the body', Dowling explains. 'Affect draws attention to a substratum of nonverbal, noncognitive communication between bodies, as one of the dimensions or registers of human relationships. It is an attention to the inter - or better trans - actions that occur between and among bodies'. ${ }^{75}$ Sensations are important - those transmitted 
across the skin are one particular focus - but human relationships and interactions form their context. ${ }^{76}$ Dowling writes of 'the joyous passions of connecting with others', for instance; Roper describes the transmission of care through touch. ${ }^{77}$ Gant, Erskine and Blackburn amply demonstrate the pleasures of connection and fellow feeling. Erskine looks contemplative while Gant views him fondly, and Blackburn smiles for the camera. Figure 6, with its men entwined, tells of an easy comfort with physical closeness.

For all the ideological separation between comradely love and eros, sometimes these tendencies slid together in practice. As D'Emilio, Freedman and others point out, 'romantic friendship coexisted with sexual relationships, overlapping at times' ${ }^{78}$ It is difficult to tell to what extent Gant's companions blurred the lines, although the photographer himself certainly did. Burly rugby player Harry Mowat provides an interesting example. He arrived in Masterton from Marlborough late in 1889 to work for the Loan and Mercantile Agency, and he and Robert Gant became close. In one image, both stand side-by-side and their caption reads 'Twice one are two' (Figure 7). In this comparison - a play on the children's height chart, possibly - Mowat's towering form emphasizes Gant's shortness.

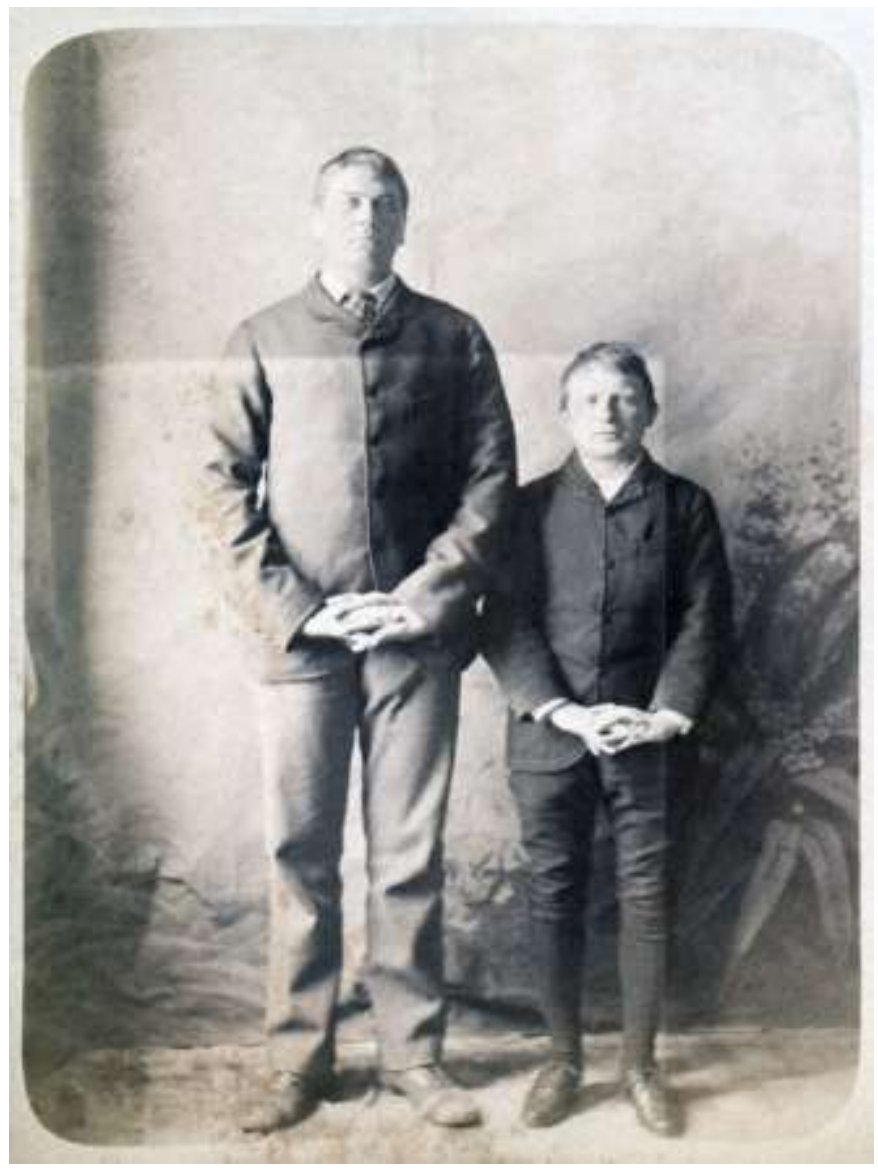

Figure 7: 'Twice one are two', featuring Mowat (left) and Gant, 1889. PA1-q-962-60-4, ATL. 
Mowat appears in other images too. Here he is again, arranged not dissimilarly to Rodin's famous statue 'Le Penseur' ('The Thinker'), with one elbow resting on a prop of some kind (Figure 8). Mowat looks contemplative, and the soft drapery intensifies the sensuousness of his skin. When Gant compiled the album, he added a caption directly underneath the image: 'Plenty of Him'. In a second image, Mowat faces the camera over the narration 'H. Mowat, aged 20', and a third photograph shows his upper chest exposed by the rips in his rugby jersey. ${ }^{79}$ In all of these images, Harry Mowat is the object of the photographer's gaze.

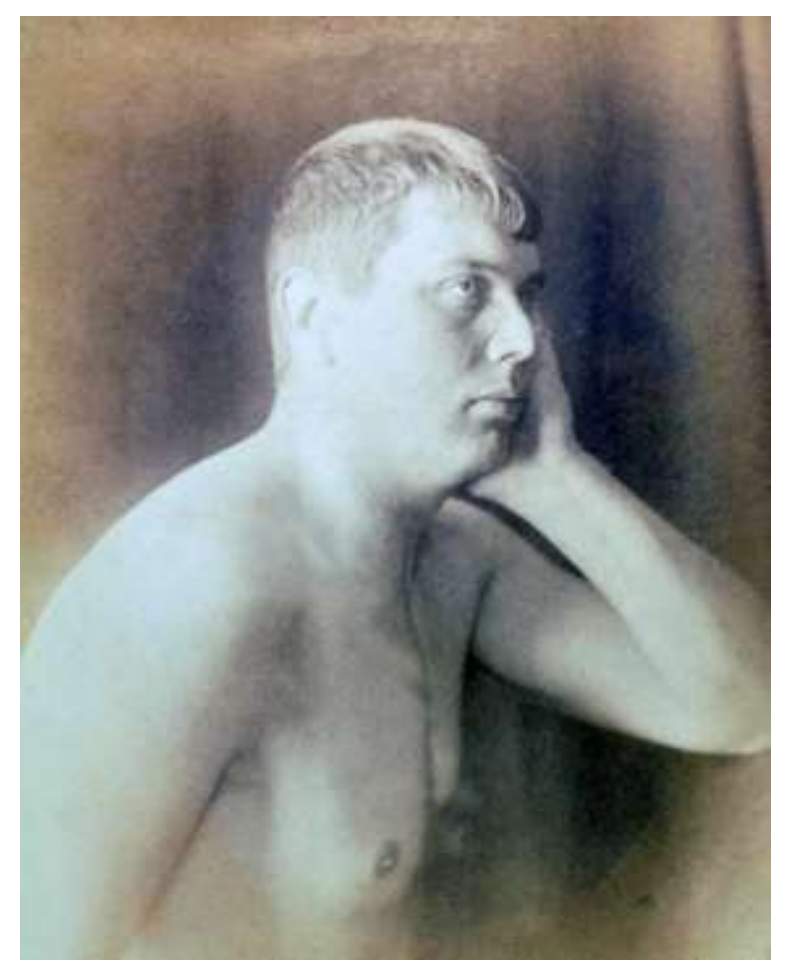

Figure 8: 'Plenty of him': Mowat on his own this time, 1889. PA1-q-962-16-1, ATL.

Mowat is the only sitter in Figure 8. Gant's portrayal differs from his photograph of the three men on the bench (Figure 6). The audience is welcomed into the intimate interaction, and Gant invites his viewers to rest their eyes on Mowat's softly-lit skin. What did it feel like for Harry, Gant seems to ask, sitting for the camera, his skin caressed by the warm air of a Wairarapa summer's day? It is a small step, perhaps, from there to an even more erotic question: what if the viewer could run his or her fingers down Mowat's arm and across his chest? What would that feel like? In this framing of feeling, Gant evokes Harry Mowat's fleshy embodiment both visually and textually ('Plenty of Him').

At this point, the lines that divide homosociality from homoeroticism become very blurry indeed. In America and Europe, some men found the ambiguities of male solidarity accommodated their erotic desires remarkably well. 'Friendship', suggests D'Arch Smith, 'meant same-sex relationships inclusive of the bedroom', and the term 'serve[d] as a password among the cognoscenti' ${ }^{80}$ Comradeship, another historian 
reminds us, 'was a sign under which many different types of masculine intimacy could be articulated'. 81

Gant's images of Mowat were not the only ones in which such ambiguities played out. An image's erotic elements were often barely disguised. Gant's oeuvre includes many a crotch shot, and he often directed men to turn around, their faces away from him, before he opened the shutter. One caption, of a group of five men, reads: 'There is character in a back view as well as in front' ${ }^{82}$ In Figure 9, Charles Blackburn poses with a knowing smile and a large hat, his legs hoisted above his head. He is clearly in on the joke even if, as seems possible, Gant cropped the resulting image before pasting it into the album. The framing - or the possible cropping - emphasized the anal focus, a focus intensified by the use of the hat.

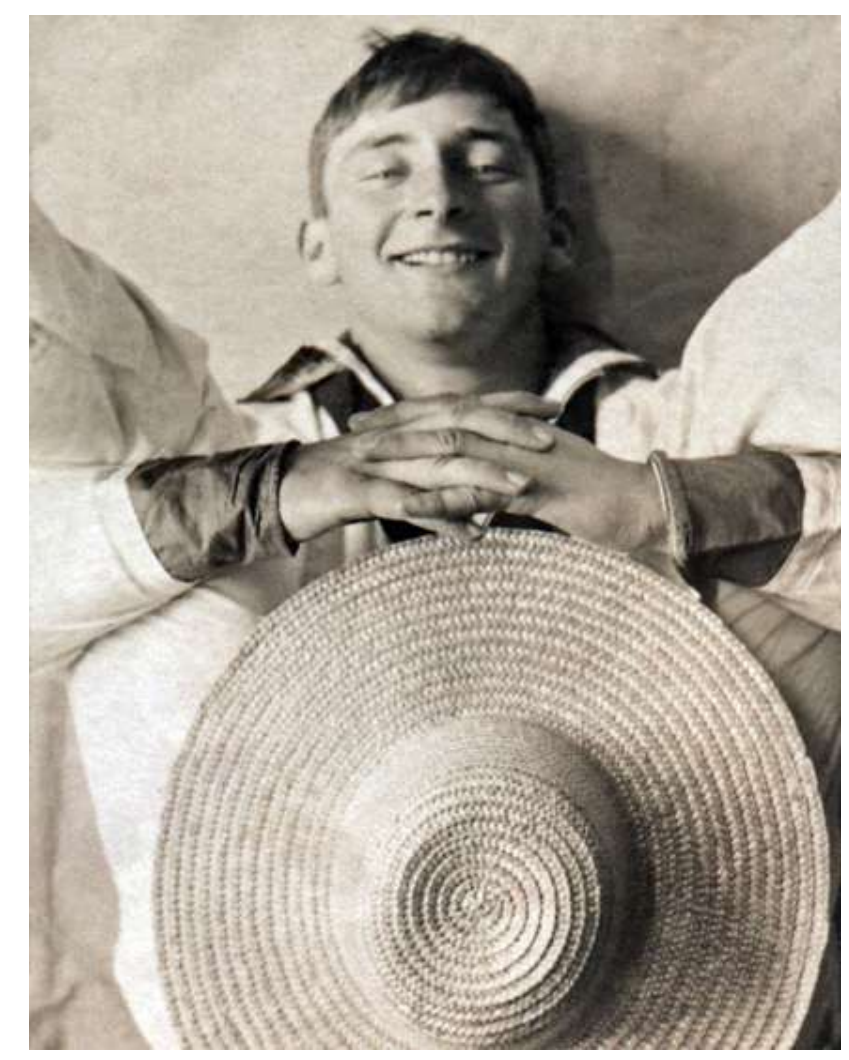

Figure 9: Blackburn and his hat, 1888. PA1-q-963-17-5, ATL.

Robert Gant's pictures urge us to reconsider the assumption that colonial men were necessarily hostile to same-sex eroticism. We know nothing about Blackburn's and Mowat's sexual desires at this stage in their lives (Blackburn married at 24 and Mowat remained unwed his entire life) but, either way, both willingly complied with Gant's instructions at the photo shoots. Blackburn appears to have found amusement in the allusion to anal sex. He was probably not alone in this regard. In another image, two men bend over to drink from the river, Gant wanders up behind them with this camera, and the resulting caption reads 'Thirsty souls'. 83

This was a world of intriguing contradictions. Robert Gant, Charles Blackburn and their friends found sodomy funny, it seems, while the legal system fulminated against an 
act most 'felonious, wicked, diabolical' and surely 'against the order of nature' ${ }^{84}$ But when it came to judicial responses to homoeroticism, the friendship pattern was highly significant. During the mid-nineteenth-century, one might level an accusation of sodomy against one's enemies. ${ }^{85}$ By the 1880 s, most of those arrested fell into two camps: those who coerced others sexually, and those of precarious social position and weak social capital. In Otago, the second group included a swagger and his mate picked up in Oamaru's gardens after a session on a blanket, a man on a prison hulk in Otago harbour, described by his antagonists as a 'dirty black brute' and dobbed in to police, and a tramp accused of improprieties with schoolboys in a Dunedin reserve. Near Kurow, an unpopular and socially isolated farm labourer was accused of having sex with a sixteenyear old cowboy. ${ }^{86}$

In other situations, however, where friendship networks were strong, male-male eroticism - whether expressed or joked about - may have constituted something of a communal glue. We can imagine the collective amusement as Blackburn raised his legs and set the hat into place, on the day the characters from H.M.S. Pinafore met in the Theatre Royal to have their photographs taken. On other occasions, men smiled as Gant set up the camera and photographed their 'back views'.

Male-male sex may have seemed unremarkable among young, unmarried men. For some of them, at least, living in a male-centred social world, with strict rules against premarital sex, homoerotic practice was probably a likely outcome. ${ }^{87}$ Court files suggest that many working-class men, at any rate, took a casual approach to their mates' consenting sexual relations. According to a constable, the conversation of the pair in the Oamaru gardens ran like this: 'Finn said "did you have a drink? All right you young bugger we'll have a fuck too". Cowley said "All right, put it up my bloody arse Jim", 88 Although both men had been strangers to one another only an hour before, the attitude is casual, their script seamless. Perhaps middle-class men followed similar patterns.

\section{Conclusion}

When we examine Robert Gant's photographs in their wider social and historical context, we see that social capital, friendship and sexuality informed one another and slide together. Settler masculinity sometimes allowed a rich field of affect and social connectedness, and even a space for eroticism. ${ }^{89}$ For these middle-class men at least, the close bonds of masculinity slotted neatly into the broader community connections.

In many ways, this was a society that differs from our own. To look at Gant's visual record, Aldrich notes, is to sense 'a different tactile world, a different set of gestures and body language from today'. ${ }^{90}$ Men were close, but the meaning of that closeness bears careful scrutiny. These men's poses and facial expressions suggest a fondness and emotionality that few New Zealand historians have so far documented. Aspects of Gant's albums suggest such connections were not unusual, and certainly no cause for alarm. Intense affect between men was not always to be avoided, a womanly attribute that threatened to mark them out from the world of robust masculinity. As Wells wrote, after a descendent of Charles Blackburn showed him the albums in 2003, neither volume is a 'private document in which perfervid images are locked away, for personal scrutiny and satisfaction'. The first of the pair 'airily features "neutral" images of bush camps, scenic views of Napier, family members. It seems to imply that there was nothing guilty or secretive about the album'. 91

Journal of New Zealand Studies NS13 (2012), 11-33. 
This holds true despite Gant's evident sexual attraction for his countrymen. That attraction manifests itself in the poses of his companions and the light that falls softly on shoulders, arms, necks and thighs. Sometimes men's touch is evocative, although the lines between eroticism and romantic friendship are not always clear. This affective world could be a fluid one. As Rotundo notes of nineteenth-century America, in the absence of a deep cultural anxiety about homosexuality, men did not have to worry about the meanings of those moments of contact'. ${ }^{92}$ As a result, friendships in the period could include 'a range of erotic, sexual and platonic possibilities'. ${ }^{93}$ For some, like Gant himself, these blurrings no doubt proved deeply rewarding. Friendship could be erotic; as Haggerty points out, masculinity is never 'one thing'. 94

Gant's friends' middle-class world differed from those of the outdoors labourers whom many authors have evoked so clearly. These were clerks, for the most part, from reasonably well-off families, white collar workers only barely aware of the privations of gold mining and bush felling, 'fifteen pounds of meat a week and no bed sheets' as Belich so eloquently puts it.

At the same time, the alignments of character and interest seem a little unusual to modern eyes. As the network diagram shows, many of these men were interested in all three of Masterton's main leisure scenes: cricket, rugby, and the arts (Figure 2). One day Blackburn, Perry or Mowat raced around the rugby field, tackling with great skill and force, and hours later they posed for Gant's camera. Later that evening, the men might sing at a concert or hop up on stage. The local newspaper reminded readers 'that drawing-room manners may be dispensed with on the football field', but evidently one could move quite easily from a muddy paddock to a drawing-room farce. ${ }^{95}$ The juxtapositions are interesting. On one page, Edmund Porritt poses proudly with his musket. Then, several pages later, he kisses Robert Gant with all the care in the world (Figures 10 and 11). Like rugby and acting, expressions of tenderness and symbols of violence were not mutually exclusive. In late-nineteenth-century Masterton, multiple strands of male existence came together.

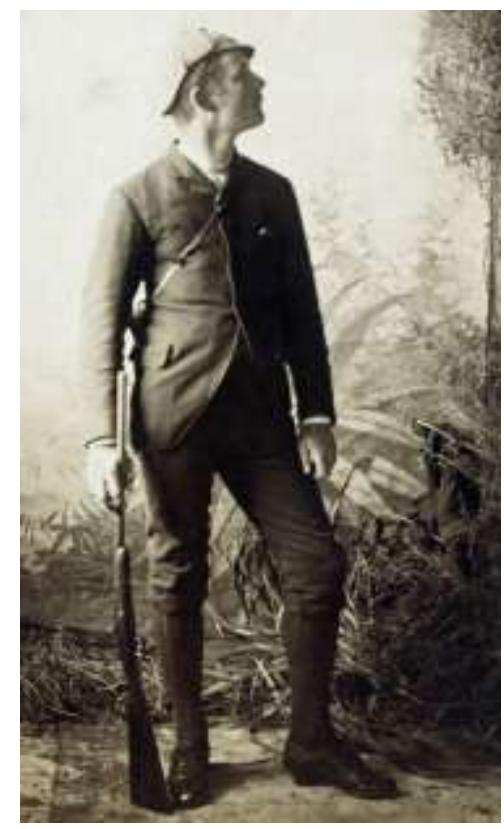




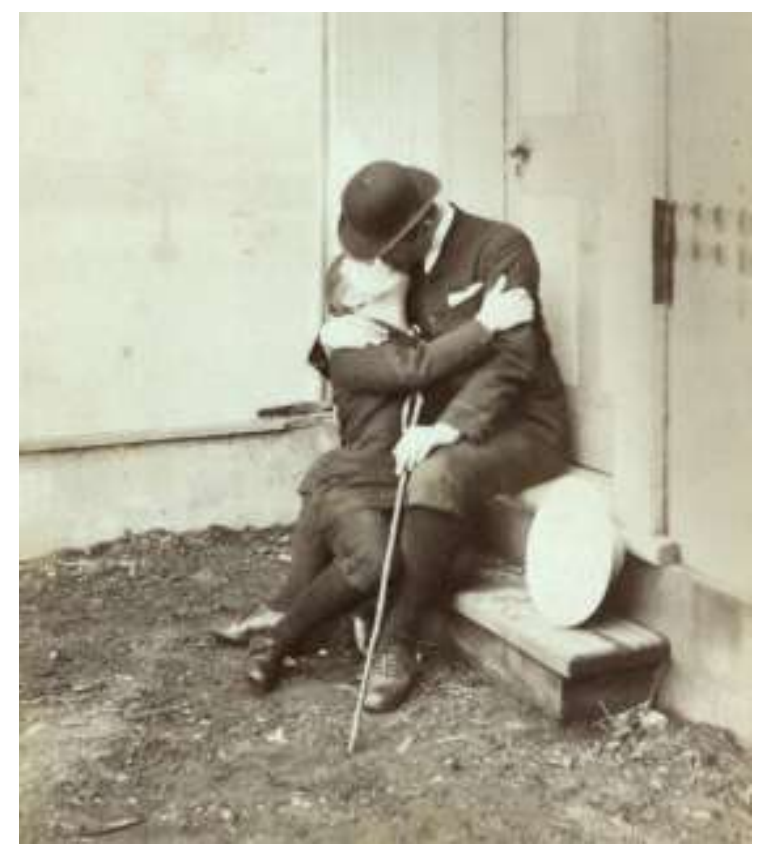

Figures 10 and 11: An intriguing juxtaposition. In the first image, Porritt poses with his gun; in the second, he kisses Gant tenderly while both sit on a doorstep. c. 1889.

$$
\text { PA1-q-962-48-5; PA1-q-962-61, ATL. }
$$

I do not for a moment wish to deny that stoicism was a feature of life for many men, that some were atomised and lonely, that drunkenness was common, that poverty hit hard and that many men fought - and sometimes even killed - one another. Porritt's gun was not for show; he was a newly-initiated member of the territorial forces, an organization to which he would belong for much of his life. ${ }^{96}$ The world of colonial masculinity was highly complex, and colonial men's lives could be richly textured.

This was a world of performativity, where actions and interactions sometimes led to new understandings and emergent social forms. Geographical movements - into and out of Masterton for a day, a year, or forever - produced a range of experiential possibilities. As people came and went, they brought in and took out novel ideas and new ways of 'doing' colonial masculinity and sociability. ${ }^{97}$ Ships and railways bought other cultural influences into settler society. Gant's own photographs, for instance, show evidence of international engagement. Not only does he allude to Rodin's statue, but one image of men swimming bears a close resemblance to American Thomas Eakins' painting 'The Swimming Hole'. Elsewhere, English genres of landscape painting make an appearance. ${ }^{98}$ Gilbert and Sullivan's comic operas, of course, along with many other English and American works, thrilled audiences in Masterton, Gore and elsewhere. It is interesting to speculate whether or not Walt Whitman's Leaves of Grass poems, which celebrated passionate comradeship, had any effect on these Masterton men. (The volume made no appearance in the library of nearby Brancepeth station, but perhaps Gant owned a copy?). ${ }^{99}$ In due course, Gant's own photographs would have informed other settlers' understandings of gender and colonial life.

And what of men in other places? Did other men's lives, in other regions, look similar to those of Robert Gant and his friends? In many ways, Gant's images are relatively 
unusual. I know of no coherent collection from the period, either nationally or internationally, which displays such a sustained degree of intimacy among the members of a single friendship group. Individual images from North America, in particular, do show men looping arms, gazing fondly at one another, hamming it up with cigarettes, guns and other props, and cross-dressing on occasion. Some are members of sports teams, others informal groups of friends. Ibson's Picturing Men is one compelling and welltheorized compilation; Deitcher's Dear Friends another. ${ }^{100}$ Few of these men are named, however, and there is no biographical detail provided for those who are. Back in New Zealand's museum and library collections, men stand in rows in sports team photos and pictures of work gangs, neither looking at one another nor touching. Still, this may be more a matter of the popularity of particular photo genres - teams and formal studio portraits especially - than a comment on their sitters' emotional worlds. Perhaps private collections contain the more intimate images.

There are a few exceptions to this apparent paucity of riches. These include the latenineteenth-century photographs of Aucklander Henry Winkelmann and his yachting associates. In the close confines below deck, four men share two bunks; one rests his hand nonchalantly on his companion's knee. ${ }^{101}$ In another, more well-known image, two sitters - presumed to be Winkelmann and his life-long friend Charlie Horton - hold hands and kiss on deck, tasting the salt on one another's lips. ${ }^{102}$ Hubert Girdlestone's albums date from the first decade of the twentieth-century. Their pages tell of the work and living conditions of surveyors in Waimarino, Ruatiti and other remote parts of the North Island. These photographs capture the men's daily activity and infuse it with a degree of intimacy. The captions are coy. Four bathing men are 'The fairy pool and the nymphs'; one surveyor asleep is 'the sleeping beauty'. In Featherston - another Wairarapa town some sitters touch shoulders and knees, their dog nestled comfortably in the middle (Figure 12). ${ }^{103}$

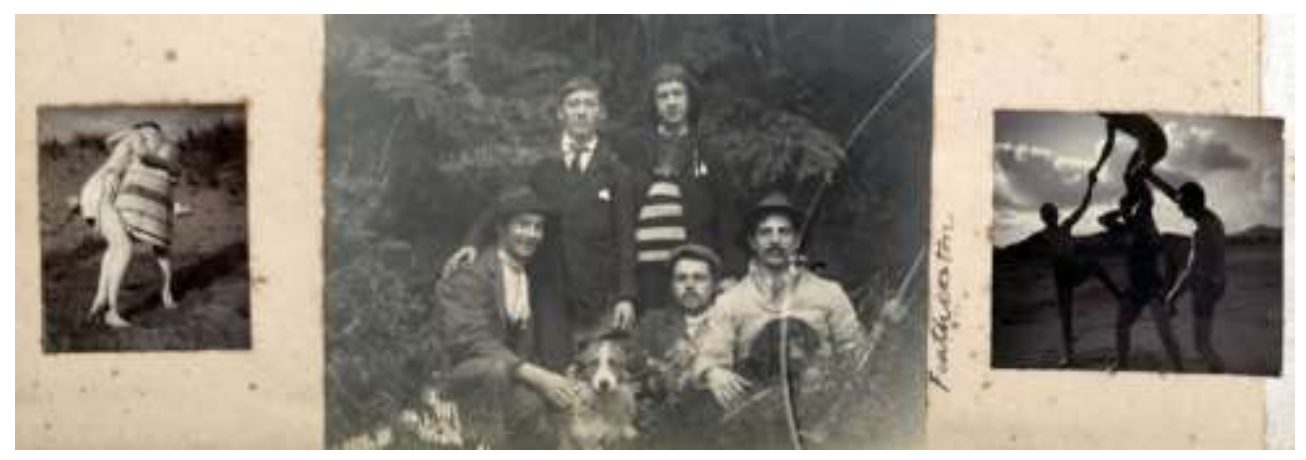

Figure 12: A trio of images from a Hubert Girdlestone album. PA1-0-1225-32-5; PA1-0-1225-32-6; PA1-0-1225-32-7, ATL.

A little later again, during the First World War, Samuel Feaver photographed rural Taranaki men from his base in Opunake. Maori and Pakeha men from the surrounding settlements - Te Kiri, Oaonui, Rahotu and Stratford - posed together in Feaver's studio. They turn to face each other and smile, lay hands on shoulders, laugh and muck about, cigarettes between their lips. ${ }^{104}$ These early-twentieth-century men are not as intimate as Robert Gant's friends, but many of the images have a charm of their own. 
Photographs cannot tell us everything, any more than novels, letters or oral histories or government reports can. All the same, they are more than mere abstractions, divorced from the warp and weft of social life. ${ }^{105}$ All who sit for the camera or write for an audience create impressions and present themselves to others. ${ }^{106}$ As researchers, we can carefully consider which sorts of impressions are made, which sorts of purposes they serve, and which kinds of social and cultural resources are drawn upon in the process. Their settings are important. The photographer's studio, the theatre's stage during a rehearsal or performance, the forest glade, or Auckland's harbour, all help to fashion the interactions captured by the camera's lens. Men are probably less likely to relax, and to be affectionate with one another, in a rugby team photo shoot than they are on a park bench in the sun, with their friend as the photographer.

No matter how representative Robert Gant's photographs may or may not be, they do sensitize us to the potentials of male companionship in late-nineteenth-century, small town New Zealand. Atomism, emotional reticence, self-contained masculinity; none of these things was inevitable in the period. Some men, at least, occupied fluid spaces of emotion and friendship, and occasionally an erotic charge infused small-town male friendship. Hands were held, bodies touched, broad shoulders were on display; these were moments of affect and connectedness. Intimacy, on a number of registers, could underpin male collective life. Robert Gant's friends were men entwined, not men alone.

\footnotetext{
${ }^{1}$ Miles Fairburn, 'Local Community or Atomised Society: The Social Structure of Nineteenth Century New Zealand', New Zealand Journal of History (NZJH), 16, 2 (1982), pp.146-67; Miles Fairburn, The Ideal Society and its Enemies: The Foundations of Modern New Zealand Society, 1850-1900, Auckland, 1989.

2 Bronwyn Dalley, 'Chance Residues: Photographs and Social History', in Tony Ballantyne and Brian Moloughney, eds., Disputed Histories: Imagining New Zealand's Pasts, Dunedin, 2006, p.189.

${ }^{3}$ Ibid., p. 169.

${ }^{4}$ Chris Brickell, Mates \& Lovers: A History of Gay New Zealand, Auckland, 2008.

5 Robin Law, Hugh Campbell and Ruth Schick, 'Introduction', in Robin Law, Hugh Campbell and Ruth Schick, eds., Masculinities in Aotearoa/New Zealand, Palmerston North, 1999, p.25.

${ }^{6}$ Stephen Whitehead and Frank Barrett, 'The Sociology of Masculinity', in Whitehead and Barrett, eds., The Masculinities Reader, Cambridge, 2001, pp.1-26.

${ }^{7}$ James Belich, Making Peoples: A History of the New Zealanders: From Polynesian Settlement to the End of the Nineteenth Century, Auckland, 1996, pp.429-31.

${ }^{8}$ Jock Phillips, A Man's Country?: The Image of the Pakeha Male, A History, Auckland, 1996, p.37.

${ }^{9}$ Ibid., p.37.

${ }^{10}$ Fairburn, 'Local Community or Atomised Society', The Ideal Society and its Enemies.

${ }^{11}$ Fairburn, 'Local Community', p.161.

${ }^{12}$ Fairburn, The Ideal Society, pp.191-7 and passim.

${ }^{13}$ Ibid., p.145.

${ }^{14}$ Gareth Winter, Two Men of Mana and Other Stories: A Celebration of Wairarapa's Early Days, Masterton, 2010, ch.14.

${ }^{15}$ Miles Fairburn, Nearly Out of Heart and Hope: The Puzzle of a Colonial Labourer's Diary, Auckland, 1995; Wairarapa Daily, 14 December 1888, p.2.

${ }^{16}$ Caroline Daley, 'Taradale Meets the Ideal Society and its Enemies', NZJH, 25, 2 (1991), pp.130-131. See also Caroline Daley, Girls \& Women, Men \& Boys: Gender in Taradale 1886-1930, Auckland, 1999.

${ }^{17}$ Matthew Wright, Reed Illustrated History of New Zealand, Auckland, 2004, p.148.

${ }^{18}$ Phillips, p.27.

${ }^{19}$ Phillips, p.28.

${ }^{20}$ Stevan Eldred-Grigg, Diggers Hatters and Whores: The Story of the New Zealand Gold Rushes, Auckland, 2008, pp.242-3.
} 
${ }^{21}$ Michael King, The Penguin History of New Zealand, Auckland, 2003, p.230.

${ }^{22}$ Fairburn, The Ideal Society, ch.5.

${ }^{23}$ Erik Olssen, Building the New World: Work, Politics and Society in Caversham, Auckland, 1995, p.228.

${ }^{24}$ Ibid., p.237.

${ }^{25}$ Claire Toynbee, 'Class and Social Structure in Nineteenth-Century New Zealand', in D.A. Hamer, ed., New Zealand Social History: Papers from the Turnbull Conference on New Zealand Social History, 1978, Auckland, 1980, p.69.

${ }^{26}$ Wright, p.126.

${ }^{27}$ Wright, p.108.

${ }^{28}$ A.G. Bagnall, Wairarapa: An Historical Excursion, Masterton, 1976, pp.307-8.

${ }^{29}$ See the discussion in Chris Brickell, Manly Affections: The Photographs of Robert Gant, 1885-1915, Dunedin, 2012, passim.

${ }^{30}$ Ibid., pp.24-7.

${ }^{31}$ King, pp.376-7.

32 James Belich, Paradise Reforged: A History of the New Zealanders, Auckland, 2001, p.512.

${ }^{33}$ Brickell, Mates \& Lovers, ch.1.

${ }^{34}$ Eve Kosofsky Sedgwick, Between Men: English Literature and Male Homosocial Desire, New York, 1985, p.1; Eve Kosofsky Sedgwick, Epistemology of the Closet, London, 1994, p.2.

${ }^{35}$ Stephen Garton, Histories of Sexuality, London, 2004, p.14 and passim; George Chauncey, Gay New York: The Making of the Gay Male World, 1890-1940, London, 1995, p.13; John D'Emilio and Estelle Freedman, Intimate Matters: A History of Sexuality in America, New York, 1998.

${ }^{36}$ Robert Putnam, Bowling Alone: The Collapse and Revival of American Community, New York, 2000.

${ }^{37}$ L.J. Hanifan, 'The Rural School Community Center', Annals of the American Academy of Political and Social Science 67 (1916), pp.130-138.

${ }^{38}$ Pierre Bourdieu, 'The Forms of Capital', in John Richardson, ed., Handbook of Theory and Research for the Sociology of Education, New York, 1986, p.248.

${ }^{39}$ Bourdieu, 'Forms of Capital', p.250.

${ }^{40}$ Wairarapa Daily, 11 Jan 1887, p.2.

${ }^{41}$ Ibid., 5 May 1888, p.2.

${ }^{42}$ Ibid., 22 June 1889, p.2.

${ }^{43}$ On the relationships between mixed-gender and segregated social opportunities in Taradale at the time, see Daley, Girls and Women, p.2.

${ }_{44}^{4}$ Wairarapa Times Age, 17 January 1944, p.2.

${ }^{45}$ Fairburn, Ideal Society, pp.181, 156.

${ }^{46}$ I read every issue of the Wairarapa Daily for 1888 and 1889, the years that correspond to the majority of Gant's photographs.

${ }^{47}$ Bourdieu, 'Forms of Capital', p.248.

${ }^{48}$ Wairarapa Daily, 6 January 1888, p.2.

${ }^{49}$ Ibid., 18 March 1889, p.2.

${ }^{50}$ Wairarapa Weekly, 21 March 1889, p.15.

${ }^{51}$ Wairarapa Daily, 4 May 1891, p.2.

${ }^{52}$ Tony Ballantyne, 'On Place, Space and Mobility in Nineteenth Century New Zealand', NZJH, 45, 1 (2011), p.63.

${ }^{53}$ W.N. Cameron, A Line of Railway: The Railway Conquest of the Rimutakas, Wellington, 1976, p.137.

${ }^{54}$ Wairarapa Daily, 24 January 1887, p.2.

${ }^{55}$ Ibid., 29 March 1889, p.2.

${ }^{56}$ Ballantyne, 'On Place, Space and Mobility', p.61.

${ }^{57}$ Greg Ryan, 'Rural Myth and Urban Actuality: The Anatomy of All Black and New Zealand Rugby', in Greg Ryan, ed., Tackling Rugby Myths: Rugby and New Zealand Society: 1854-2004, Dunedin, 2005, p. 45.

${ }^{58}$ Wairarapa Daily, 24 January 1888, p.2.

${ }^{59}$ New Zealand Free Lance, 29 May 1909, p.4.

${ }^{60}$ Wairarapa Daily, 23 January 1889, p.2.

${ }^{61}$ Joanna Woods, Facing the Music: Charles Baeyertz and the Triad, Dunedin, 2008, pp.58-59. 
${ }^{62}$ Ballantyne, 'Thinking Local: Knowledge, Sociability and Community in Gore's Intellectual life, 18751914', NZJH, 44, 2 (2010), pp.138-56, esp. p.145.

${ }^{63}$ W.G. Bishop memoir, ARC-2002-160, Puke Ariki, New Plymouth.

${ }^{64}$ Daley, 'Taradale', p.140.

${ }^{65}$ Wairarapa Daily, 7 November 1888, p.2; 18 March 1887, p.2; 25 May 1888, p.2; 18 September 1888, p.2; 26 July 1888, p.2; Evening Post, 31 December 1886, p.2.

${ }^{66}$ Wairarapa Daily, 10 October 1888, p.2.

${ }^{67}$ Sedgwick, Between Men, p.2. Emphasis in original.

${ }^{68}$ John Tosh, A Man's Place: Masculinity and the Middle-Class Home in Victorian England, New Haven, 1999, p.173.

${ }^{69}$ Peter Gay, The Bourgeois Experience: Victoria to Freud: The Tender Passion, Volume 2, New York, 1986, p.217.

${ }^{70}$ E. Anthony Rotundo, 'Romantic Friendship: Male Intimacy and Middle-Class Youth in the Northern United States, 1800-1900', Journal of Social History, 23, 1 (1989), p.8. See also William Benemann, MaleMale Intimacy in Early America: Beyond Romantic Friendships, New York, 2006.

${ }^{71}$ John Gillis, Youth and History: Tradition and Change in European Age Relations 1770-Present, New York, 1974, p.106.

${ }^{72}$ Ibid., p.105.

${ }^{73}$ Jonathan Ned Katz, Love Stories: Sex Between Men Before Homosexuality, Chicago, 2010, pp.36-39.

${ }^{74}$ Melissa Gregg and Gregory Seigworth, eds., The Affect Theory Reader, Durham, 2010; Nigel Thrift, 'Intensities of Feeling: Towards a Spatial Politics of Affect', Geografiska Annaler: Series B, Human Geography, 86, 1 (2004), pp.57-78.

${ }^{75}$ Emma Dowling, 'The Waitress: On Affect, Method, and (Re)presentation', Cultural Studies, Critical Methodologies, 12, 2 (2012), p.115.

${ }^{76}$ See, for example, Marc Lafrance, 'Skin and the Self: Cultural Theory and Anglo-American Psychoanalysis', Body and Society 15, 3 (2009), pp.3-24.

77 Dowling, 'The Waitress', p.112; Michael Roper, 'Slipping Out of View: Subjectivity and Emotion in Gender History’, History Workshop Journal, 59, 1 (2005), pp.68-69.

${ }^{78}$ D'Emilio and Freedman, Intimate Matters, p.121; see also Karen Hansen, “'Our Eyes Behold Each Other": Masculinity and Intimate Friendship in Antebellum New England', in Peter Nardi, ed., Men's Friendships, Newbury Park, 1992, p.45.

${ }^{79}$ Brickell, Manly Affections, p.101.

${ }^{80}$ Timothy D'Arch Smith, 'Introduction', The Quorum: A Magazine of Friendship, Hanover, NH, 2001, p.2.

${ }^{81}$ H.G. Cocks, Nameless Offences: Homosexual Desire in Nineteenth Century London, London, 2003, p. 160 .

${ }_{83}^{82}$ Brickell, Manly Affections, pp.88-89.

${ }^{83}$ Ibid., p.22.

${ }^{84}$ Brickell, Mates \& Lovers, p.39.

${ }^{85}$ Ibid., p.30.

${ }^{86}$ Chris Brickell, 'Sex, Space and Scripts: Negotiating Homoeroticism in History', Social and Cultural Geography 11, 6 (2010), pp.597-613. The last-mentioned case is not covered in this article, but details can be found in W. King, Trial File, DAAC D256 395 13, 1896, Archives New Zealand.

${ }^{87}$ Robert Aldrich, Colonialism and Homosexuality, London, 2003, pp.240-41.

${ }^{88}$ Brickell, Mates \& Lovers, p.45.

${ }^{89}$ On affect, sexuality and masculinity in the eighteenth-century, see David Halperin, 'Introduction: Among Men - History, Sexuality, and the Return to Affect', in Katherine O'Donnell and Michael O'Rourke, eds., Love, Sex, Intimacy, and Friendship Between Men, 1550-1800, Houndmills, 2003, pp.1-11.

${ }^{90}$ Robert Aldrich, personal communication with author.

${ }^{91}$ Peter Wells, 'Have a Look at Me', New Zealand Listener, 29 November 2003, pp.28-29.

${ }^{92}$ E. Anthony Rotundo, American Manhood: Transformations in Masculinity from the Revolution to the Modern Era, New York, 1993, p.85.

${ }_{93}$ Peter Nardi, Gay Men's Friendships, Chicago, 1999, p.31. See also Benemann, Male-Male Intimacy, p.xiv; D'Emilio and Freedman, Intimate Matters, p.121. 
${ }^{94}$ George Haggerty, Men in Love: Masculinity and Sexuality in the Eighteenth Century, New York, 1999, p.5. On the variability of colonial masculinity see also Daley, 'Taradale', p.146.

${ }_{95}$ Wairarapa Daily, 13 May 1889, p.2.

${ }^{96}$ Ohinemuri Gazette, 25 October 1909, p.3.

${ }^{97}$ On 'doing masculinity' see Don West and Candice Zimmerman, 'Doing Gender', in Judith Lorber and Susan Farrell, eds., The Social Construction of Gender, Newbury Park, 1991, pp.13-37.

${ }_{98}^{98}$ Brickell, Manly Affections, passim.

${ }^{99}$ On the Brancepeth library see Lydia Wevers, Reading on the Farm: Victorian Fiction and the Colonial World, Wellington, 2010.

${ }^{100}$ David Deitcher, Dear Friends: American Photographs of Men Together, 1840-1918, New York, 2001; John Ibson, Picturing Men: A Century of Male Relationships in Everyday American Photography, Chicago, 2002. See also Russell Bush, Affectionate Men: A Photographic History of a Century of Male Couples (1850's to 1950's), New York, 1998; James Gardiner, Who's a Pretty Boy Then? One Hundred and Fifty Years of Gay Life in Pictures, London, 1998.

${ }^{101}$ Robin Elliott, Harold Kidd and Rodney Wilson, Winkelmann's Waitemata: Classic Auckland Yachting Auckland, 1998, back cover.

${ }^{102}$ This image was published on the front cover of Peter Wells and Rex Pilgrim, eds., Best Mates: Gay Writing in Aotearoa New Zealand, Auckland, 1997. See also Brickell, Mates \& Lovers, pp.384-5.

${ }_{103}$ There are eight albums in total. These examples can be found in PA1-q-913, PA1-q-914, PA1-q-915, PA1-0-1223 and PA1-o-1225, Alexander Turnbull Library.

${ }^{104}$ Chris Brickell, 'Men Together: Intimacy and Eroticism in Pre-World War I New Zealand', in Yorick Smaal and Graham Willett, eds., Gay and Lesbian Perspectives VII, Melbourne, forthcoming in 2013.

These images can be found in a set of file drawers at Puke Ariki in New Plymouth.

${ }^{105}$ Burke, Eyewitnessing, pp.183-5.

${ }^{106}$ Erving Goffman, 'Picture Frames', in Peter Hamilton, ed., Visual Research Methods, Volume 3, London, 2006, pp.31-33. 